\title{
Comprehensive primary health facilities are more efficient in delivering primary care: Efficiency analysis of primary healthcare facilities in Afghanistan
}

Farhad Farewar ( $\square$ hefd.farewar@gmail.com )

Ministry of Public Health https://orcid.org/0000-0003-3893-5541

Khwaja Mir Ahad Saeed

Health Economics and Financing Directorate

Abo Ismael Foshanji

Health Economics and Financing Directorate

Said Mohammad Karim Alawi

Health Economics and Financing Directorate

Mohammad Yonus Zawoli

The Palladiumgroup

Sinai Irit

The Palladium Group

Wu Zeng

Brandeis University Heller School for Social Policy and Management

Research article

Keywords: Technical efficiency, Primary healthcare, Data Envelopment Analysis

Posted Date: November 25th, 2019

DOI: https://doi.org/10.21203/rs.2.17694/v1

License: (c) (1) This work is licensed under a Creative Commons Attribution 4.0 International License. Read Full License 


\section{Abstract}

Background The Afghan health system is unique in that primary healthcare is delivered by donor-funded implementing partners, not the government. Given the wide range of implementers providing the basic package of health services, there may exist performance differences in primary healthcare. This study assessed the relative efficiency of different levels of primary healthcare services and explored its determinants in Afghanistan.

Method Data on personnel and capital expenditure (inputs) and the number of facility visits for six primary healthcare services (outputs) were obtained from national health information databases for 1,263 healthcare facilities in 31 provinces. Data envelopment analysis was used to assess the relative efficiency of three levels of primary healthcare facilities (comprehensive, basic, and sub health centers). Bivariate analysis was conducted to assess the correlation of various elements with efficiency scores. Regression models were used to identify potential factors associated with efficiency scores at the health facility level.

Results The average efficiency score of health facilities was 0.74 , when pooling all 1,263 health facilities, with 102 health facilities (8.1\%) having efficiency scores of 1 (100\% efficient). The lowest quintile of health facilities had an average efficiency score of 0.36 while the highest quintile had a score of 0.96 . On average, efficiency scores of comprehensive health centers were higher than basic and sub health centers by 0.108 and .071 respectively. In addition, the difference between efficiency scores of facilities in the highest and lowest quintiles was highest in facilities that offer fewer services, so that they have the largest room for improvement.

Conclusions Our findings show that public health facilities in Afghanistan that provide more comprehensive primary health services, use their resources more efficiently, and that smaller facilities have more room for improvement. A more integrated delivery model would help improve the efficiency in providing primary healthcare in Afghanistan.

\section{Background}

The government of Afghanistan is committed to achieving the Sustainable Development goal of universal health coverage. However, while primary healthcare in the country is perceived to be donor dependent, in reality, a large proportion of total health spending is born directly by households []. To move towards universal health coverage requires the government to take multifaceted interventions. Therefore, in addition to the Ministry of Public Health's efforts to seek ways to increase the government share of total health expenditure, improving efficiency - or the more efficient use of available resources - is considered to be one of the pillars of increased fiscal space for service delivery [. Insufficient funding can be due not only to lack of funds, but also to inefficient spending of existing resources [. More efficient use of resources has been linked to increased access to health services [. 
The struggle to reduce inefficiencies in the health sector is not unique to Afghanistan. International evidence suggests that inefficiency across health facilities in low-income countries is widespread []. For instance, a study in Ghana showed that the average efficiency score of health centers was 0.51 , which means that $49 \%$ of resources could have been saved if the health centers ran optimally and shows a potential opportunity for improvement [5].

Following two decades of war and the resulting collapse of public-health institutions, the new government of Afghanistan reshaped the healthcare system, including primary healthcare, in 2002. Since then, the Basic Package of Health Services (BPHS) provides an umbrella of priority health services. In 31 of the country's 34 provinces, the BPHS is not provided directly by the government. Rather, these services have been contracted out to non-governmental organizations (NGOs), funded by a variety of donors (United States Agency for International Development (USAID), the World Bank, and the European Union). In the remaining three provinces, health services are provided directly by the Afghan government, under the Strengthening Mechanism Project [.

With the expansion of primary health services through BPHS, more people are able to access healthcare. Meanwhile, the funding gaps are widening over time and improving efficiency in health service delivery has become increasingly critical to address them. In 2016, Health Economics and Financing Directorate (HEFD) of the Afghanistan Ministry of Public Health conducted fiscal space analysis and identified inefficiencies as a key area for increasing fiscal space for health [2]. Several studies have been conducted in Afghanistan to evaluate the efficiency of service delivery,. In 2014, Blaakman et al. compared the efficiency of health services in the three provinces in which the Afghan government provides services directly, to three provinces where services are contracted out to NGOs [. The study found that the cost per unit of outpatient visits is higher in NGO provinces, suggesting the existence of potential inefficiency in NGO-run facilities. In Afghanistan, BPHS is offered in six standard types of health facilities, ranging from community outreach provided by community health workers in health posts, through outpatient care at health sub centers (HSCs), basic health centers (BHCs) and mobile health teams (MHTs), to inpatient services at comprehensive health centers (CHCs) and district hospitals ( $\mathrm{DHs})^{[}{ }^{[15}{ }^{]}$. Different health facilities have varying sets of standard inputs, such as the number and qualification of staffing, that affect both inputs and outputs of service delivery and thus affect the efficiency.

Given the complexity of BPHS delivery and the recent decrease in donor aid, efficiency enhancement has become a priority task for the Ministry of Public Health in Afghanistan. The current study looked closer at the efficiency of various types of health facilities in provinces where healthcare services are operated by NGOs, and compared technical efficiency among them in Afghanistan.

\section{Methods}

Data sources 
The study focused on three levels of health facilities: CHCs, BHCs, and SHCs, although there are six types of facilities delivering BPHS in Afghanistan. The selected three types of facilities consume the most resources for BPHS. Each level provides services of various complexity and cover different population sizes; hence, requiring different categories and number of staffing.

To assess efficiency of health facilities we obtained facility health expenditure data from the Expenditure Management Information System (EMIS) which is centrally managed by the Afghanistan Ministry of Public Health. The EMIS includes indicators on health facility human resource expenditures (e.g. medical, administrative, and supporting staff), capital investments (e.g. equipment, machinery and tools), and other recurrent costs of operating health facilities and providing health services. These are our input variables. In addition, we acquired from the Afghanistan Health Management Information System (HMIS) data on a number of outpatient visits, by type of service received. These are our output variables. The HMIS also provided information on the number of different types of personnel employed in each health facility (additional input factors).

Both EMIS and HMIS have been institutionalized in Afghanistan for many years. They are collected quarterly and are considered to be reliable. All data were extracted for the full 2016 calendar year.

Afghanistan has 34 provinces. Only 31 provinces report to the EMIS. These are the provinces in which health facilities are operated by NGOs. All health facilities in these provinces were considered for analysis. We excluded facilities with 'outlier' expenditures - facilities whose expenditure was plus/minus three standard deviations from the mean facility expenditure. This resulted in a total of 1,263 facilities included in the analysis: 272 CHCs, 571 BHCs and 420 SHCs.

Analytic approach

To estimate the efficiency of health facilities, we used Data Envelopment Analysis (DEA), a classic nonparametric approach to calculating a measure of technical efficiency. The DEA uses the following formula to assign an efficiency score to each health facility. Specifically, we used input-oriented DEA with variable returns to scale [,]. This approach would help understand potential savings for given outputs. The efficiency scores were estimated as a ratio of weighted outputs to weighted inputs (see formula below), where the weights were calculated by the statistical software automatically by maximizing the ratio for each decision making unit under the evaluation, while ensuring that the ratio, when applied to other decision making units, would be between 0 and 1. As DEA has been widely described elsewhere $[8,9,10]$, the derivation of efficiency scores using DEA is not repeated here.

$$
\text { Efficiency Score }=\frac{\sum \text { weighted outputs }}{\sum \text { weighted inputs }} \mid
$$

An advantage of DEA is that it provides considerable flexibility in data selection and can incorporate multiple input and output variables, which can be continuous, ordinal, or categorical. [3]. 
In this study, we conducted two DEAs. In the first, we calculated separate efficiency scores for the three levels of facilities: SHC, BHC, and CHC (referred to as "separate efficiency scores"). By the scores we assumed that each type of facilities has its own production frontier. With the calculated input-oriented efficiency scores from this analysis, we were able to estimate potential savings, which is the product of health expenditure and the complement of the efficiency scores. DEA estimates an efficiency score for each health facility, ranging from 0 to 1 . An efficiency score of 1 means that the health facility has maximum efficiency, while an efficiency score of 0 suggests that the health facility does not produce any outputs. As the efficiency estimation for the three types of facilities used different production frontiers, the efficiency scores could not be compared across different type facilities. In the second DEA, we pooled all three types of facilities together, assuming a single production frontier (referred to as "pooled efficiency scores"). The efficiency scores from the pooled sample allows for the comparison of efficiency scores across different types of facilities.

To measure expenditures (inputs) we included the following indicators: (1) number of clinical personnel reported for the fourth quarter, (2) number of non-clinical personnel, including administrative and supporting staff, reported for the fourth quarter, (3) non-personnel recurrent expenditure (total for the year), and (4) capital expenditure (total for the year). These four indicators capture most of the resources used by health facilities to provide services. While expenditure information in the EMIS is in Afghan currency, the Ministry of Public Health makes programmatic decisions in United States Dollars (USD). Therefore, we converted all expenditure data into USD, using the annual average Afghanistan Central Bank official exchange rate. In the multivariate analysis expenditure variables were converted to their logarithmic form.

To measure services (output) we included number of visits (by adults and children of all ages) associated with the following conditions in the course of the year: (1) acute respiratory infection, (2) diarrhea, (3) peptic disorder, (4) number of immunizations administered (5) number of antenatal and postnatal visits, and (6) number of all other facility visits.

These input and output indicators were used to create the health-facilities efficiency scores. The scores range $0-1$, where 1 means maximum efficiency. In the multivariate analysis these scores are the dependent variable. Our explanatory variables are: (1) proportion of facility personnel who are supporting staff (calculated by dividing the number of supporting staff by the number of all facility personnel; (2) proportion of capital costs, from among total annual costs; and (3) province hardship category. The latter is a measure used by the Ministry of Public Health in deciding salary scales, and reflects remoteness and the security situation in the province. It consists of four categories. We created three dummy variables, with category one (least hardship category) as the reference category. These variables were selected based on knowledge of the health system in Afghanistan which suggested that these factors might influence efficiency.

\section{Statistical analysis}


To start, we conducted descriptive analysis of all the variables included in the efficiency calculations, as well as the explanatory variables. For continuous variables, means and standard deviations were calculated, while frequencies are shown for categorical variables. We then used ordinary least square regression to assess determinants of variation in efficiency at the health facility level, first by type of health facilities and then by pooling the three types of facilities together. The dependent variables were the facility-specific efficiency scores calculated by the DEA, separated by type of facility and pooled together, for the two analyses respectively. Data were extracted in MS Excel. All statistical analyses were conducted using STATA v.15, except the calculation of the DEA score, which was calculated using $R$ (version 3.5.3).

\section{Results}

Facility characteristics

In total, 1,263 health facilities from 31 provinces were included in the analysis: $272 \mathrm{CHCs}, 571 \mathrm{BHCs}$, and 420 SHCs. Table 1 describes the various variables used to calculate the health-facility efficiency scores, as well as select contextual variables. On average, the annual capital expenditure was USD\$3,908 in CHC, USD $\$ 1,375$ per BHC, and USD $\$ 918$ per SHC, while the recurrent expenditure was USD\$38,601 per CHC, USD $\$ 15,680$ per BHC and USD\$8,661 per SHC.

\section{Table 1}

Description of inputs, outputs and explanatory variables by facility level 


\begin{tabular}{|c|c|c|c|c|c|c|}
\hline \multirow[b]{2}{*}{ Variable } & \multicolumn{2}{|c|}{$\mathrm{CHC}(n=272)$} & \multicolumn{2}{|c|}{$\mathrm{BHC}(n=571)$} & \multicolumn{2}{|c|}{$\operatorname{SHC}(n=420)$} \\
\hline & $\begin{array}{l}\text { Mean } \\
(\mathrm{SD})\end{array}$ & Range & $\begin{array}{l}\text { Mean } \\
\text { (SD) }\end{array}$ & Range & $\begin{array}{l}\text { Mean } \\
\text { (SD) }\end{array}$ & Range \\
\hline \multicolumn{7}{|l|}{ Input variables } \\
\hline Capital cost (USD) & $\begin{array}{l}3,908 \\
(12,433)\end{array}$ & $0-133,501$ & $\begin{array}{l}1,375 \\
(3,011)\end{array}$ & $\begin{array}{l}0- \\
26,179\end{array}$ & $\begin{array}{l}918 \\
(1,781)\end{array}$ & $\begin{array}{l}0- \\
15,725\end{array}$ \\
\hline Recurrent cost (USD) & $\begin{array}{l}38,601 \\
(25,077)\end{array}$ & $\begin{array}{l}5,855- \\
259,568\end{array}$ & $\begin{array}{l}15,680 \\
(7,679)\end{array}$ & $\begin{array}{l}231- \\
54,789\end{array}$ & $\begin{array}{l}8,661 \\
(5,069)\end{array}$ & $\begin{array}{l}28- \\
32,521\end{array}$ \\
\hline \# supporting staff & $\begin{array}{l}4.57 \\
(1.3)\end{array}$ & $0-8$ & $\begin{array}{l}1.99 \\
(0.63)\end{array}$ & $0-14$ & $\begin{array}{l}1 \\
(0.50)\end{array}$ & $0-10$ \\
\hline \# technical staff & $\begin{array}{l}10.38 \\
(1.43)\end{array}$ & $2-18$ & $\begin{array}{l}5.35 \\
(1.02)\end{array}$ & $1-16$ & $\begin{array}{l}2.47 \\
(0.68)\end{array}$ & $1-5$ \\
\hline \multicolumn{7}{|l|}{ Output variables } \\
\hline $\begin{array}{l}\text { \# acute respiratory } \\
\text { infection visits }\end{array}$ & $\begin{array}{l}11,590 \\
(5,924)\end{array}$ & $0-39,166$ & $\begin{array}{l}6,540 \\
(3,586)\end{array}$ & $\begin{array}{l}653- \\
23,101\end{array}$ & $\begin{array}{l}3,952 \\
(2,141)\end{array}$ & $\begin{array}{l}294- \\
16,426\end{array}$ \\
\hline \# diarrhea visits & $\begin{array}{l}42.55 \\
(2,417)\end{array}$ & $0-19,437$ & $\begin{array}{l}2,449 \\
(1,526)\end{array}$ & $\begin{array}{l}105- \\
11,500\end{array}$ & $\begin{array}{l}1,521 \\
(908)\end{array}$ & $\begin{array}{l}9- \\
6452\end{array}$ \\
\hline \# peptic disorder visits & $\begin{array}{l}3,024 \\
(1,579)\end{array}$ & $0-9,933$ & $\begin{array}{l}1,705 \\
(985)\end{array}$ & $\begin{array}{l}101- \\
8,478\end{array}$ & $\begin{array}{l}1,123 \\
(632)\end{array}$ & $\begin{array}{l}69- \\
3,962\end{array}$ \\
\hline $\begin{array}{l}\text { \# immunization } \\
\text { administered }\end{array}$ & $\begin{array}{l}7,592 \\
(4,132)\end{array}$ & $\begin{array}{l}580- \\
26,213\end{array}$ & $\begin{array}{l}4,774 \\
(2,710)\end{array}$ & $\begin{array}{l}0- \\
17,778\end{array}$ & $\begin{array}{l}1,053 \\
(1,576)\end{array}$ & $\begin{array}{l}0- \\
10,219\end{array}$ \\
\hline $\begin{array}{l}\text { \# antenatal \& postnatal } \\
\text { visits }\end{array}$ & $\begin{array}{l}6,827 \\
(4,907)\end{array}$ & $0-32,286$ & $\begin{array}{l}3,155 \\
(2,552)\end{array}$ & $S$ & $\begin{array}{l}1,573 \\
(1,265)\end{array}$ & $\begin{array}{l}0- \\
8,072\end{array}$ \\
\hline \# other visits & $\begin{array}{l}25,667 \\
(12,898)\end{array}$ & $\begin{array}{l}400- \\
76,965\end{array}$ & $\begin{array}{l}13,051 \\
(6,864)\end{array}$ & $\begin{array}{l}622- \\
49,187\end{array}$ & $\begin{array}{l}7,809 \\
(4,381)\end{array}$ & $\begin{array}{l}642- \\
48,044\end{array}$ \\
\hline \multicolumn{7}{|l|}{ Explanatory variables } \\
\hline$\%$ supporting staff & $\begin{array}{l}0.3 \\
(0.06)\end{array}$ & $0-0.47$ & $\begin{array}{l}0.27 \\
(0.06)\end{array}$ & $0-0.78$ & $\begin{array}{l}0.28 \\
(0.11)\end{array}$ & $0-0.77$ \\
\hline$\%$ capital cost & $\begin{array}{l}0.06 \\
(0.13)\end{array}$ & $0-0.82$ & $\begin{array}{l}0.07 \\
(0.13)\end{array}$ & $0-0.78$ & $\begin{array}{l}0.09 \\
(0.15)\end{array}$ & $0-0.85$ \\
\hline
\end{tabular}

Values for all input and output variables were largest for CHCs, followed by BHCs, with SHCs having the smallest input and output values, reflecting the relative sizes of these types of facilities. Mean of the contextual variables was very similar across facility types.

Comparative Efficiency Separated by Type of Facilities 
In general, $\mathrm{CHCs}$ had a higher average efficiency scores than BHCs and SHCs. The mean $\mathrm{CHC}$ score in the lowest efficiency quintile was fairly high at 0.84 , yet there was still room for improvement for facilities in the lowest efficiency quintile up to 0.16 to be fully efficient. In comparison, in BHCs the difference between mean efficiency scores in the highest quintile (0.94) and the lowest quintile (0.67) was 0.27 . For SHCs the difference between highest and lowest quintiles was greatest at 0.40 . We can also see that the mean efficiency scores in the highest quintile was fairly similar in all type of health facilities. The bigger differences were in the bottom two quintiles.

Table 2 shows the ordinary least square regressions of the determinants of efficiency. In BHCs, the explanatory variables were statistically significant, except share of supporting staff. If share of capital cost increases by 1 percentage point, the efficiency would decrease by 0.10 percentage points.

Additionally, compared to province group 1 , groups 2,3 , and 4 had a relatively lower efficiency score, by $4.4,2.8$, and 4.5 percentage points. In SHCs, the share of supporting staff and location were statistically significant. If share of supporting staff increases by 1 percentage point, the efficiency score would be reduced by 0.30 percentage points. Additionally, compared to provinces in group 1 , the efficiency in group 2 was significantly lower.

Table 2

Regression model of the efficiency at the CHCs, BHCs and SHCs 


\begin{tabular}{|c|c|c|c|c|c|c|}
\hline & \multicolumn{2}{|l|}{$\mathrm{CHC}$} & \multicolumn{2}{|l|}{$\mathrm{BHC}$} & \multicolumn{2}{|l|}{ SHC } \\
\hline & $\begin{array}{l}\text { Coefficient } \\
\text { (Standard } \\
\text { error) }\end{array}$ & $\begin{array}{l}95 \% \\
\text { confidence } \\
\text { interval }\end{array}$ & $\begin{array}{l}\text { Coefficient } \\
\text { (Standard } \\
\text { error) }\end{array}$ & $\begin{array}{l}95 \% \\
\text { confidence } \\
\text { interval }\end{array}$ & $\begin{array}{l}\text { Coefficient } \\
\text { (Standard } \\
\text { error) }\end{array}$ & $\begin{array}{l}95 \% \\
\text { confidence } \\
\text { interval }\end{array}$ \\
\hline $\begin{array}{l}\% \\
\text { supporting } \\
\text { staff }\end{array}$ & $\begin{array}{l}-0.178^{\star \star \star} \\
(0.052)\end{array}$ & $\begin{array}{l}-0.28- \\
-0.076\end{array}$ & $\begin{array}{l}-0.067 \\
(0.068)\end{array}$ & $\begin{array}{l}-0.201- \\
0.068\end{array}$ & $\begin{array}{l}-0.297^{\star \star \star} \\
(0.065)\end{array}$ & $\begin{array}{l}-0.426- \\
-0.169\end{array}$ \\
\hline $\begin{array}{l}\% \text { capital } \\
\text { cost }\end{array}$ & $\begin{array}{l}0.019 \\
(0.025)\end{array}$ & $-0.03-0.069$ & $\begin{array}{l}0.103^{\star \star \star \star} \\
(0.032)\end{array}$ & $0.039-0.165$ & $\begin{array}{l}0.031 \\
(0.047)\end{array}$ & $\begin{array}{l}-0.062- \\
0.124\end{array}$ \\
\hline $\begin{array}{l}\text { Hardship } \\
\text { province } 2\end{array}$ & $\begin{array}{l}-0.002 \\
(0.01)\end{array}$ & $-0.21-0.017$ & $\begin{array}{l}-0.044^{\star \star * *} \\
(0.011)\end{array}$ & $\begin{array}{l}-0.067- \\
-0.020\end{array}$ & $\begin{array}{l}-0.049 * \\
(0.025)\end{array}$ & $\begin{array}{l}-0.098- \\
0.001\end{array}$ \\
\hline $\begin{array}{l}\text { Hardship } \\
\text { province } 3\end{array}$ & $\begin{array}{l}-0.008 \\
(0.01)\end{array}$ & $-0.027-0.012$ & $\begin{array}{l}-0.028 * \star \star \\
(0.012)\end{array}$ & $\begin{array}{l}-0.052- \\
-0.004\end{array}$ & $\begin{array}{l}-0.023 \\
(0.024)\end{array}$ & $\begin{array}{l}-0.075- \\
0.020\end{array}$ \\
\hline $\begin{array}{l}\text { Hardship } \\
\text { province } 4\end{array}$ & $\begin{array}{l}-0.02 * \\
(0.011)\end{array}$ & $-0.041-0$ & $\begin{array}{l}-0.045^{\star \star \star} \\
(0.011)\end{array}$ & $\begin{array}{l}-0.067- \\
-0.021\end{array}$ & $\begin{array}{l}-0.027 \\
(0.024)\end{array}$ & $\begin{array}{l}-0.075- \\
0.020\end{array}$ \\
\hline Constant & $\begin{array}{l}0.961 * \star \star \\
(0.019)\end{array}$ & $0.925-0.998$ & $\begin{array}{l}0.83^{\star} \\
(0.019)\end{array}$ & $0.791-0.868$ & $\begin{array}{l}0.84^{\star \star \star} \\
(0.026)\end{array}$ & $\begin{array}{l}0.788- \\
0.892\end{array}$ \\
\hline \multicolumn{7}{|c|}{$\star \star \star, * *, \& *$ denote significance at the $p<0.01, p<0.05, \& p<0.1$ respectively } \\
\hline \multicolumn{7}{|c|}{ Comparative Efficiency by Pooling all Health Facilities } \\
\hline \multicolumn{7}{|c|}{$\begin{array}{l}\text { When pooling all health facilitates using a single production frontier, we found that the average } \\
\text { efficiency score was } 0.74 \text { with a standard deviation of } 0.25 \text {. Out of } 1,263 \text { health facilities, } 102 \text { were on } \\
\text { the production frontier, of which } 32 \text { were CHCs, } 30 \text { BHCs, and } 40 \text { SHCs. The efficient health facilities } \\
\text { accounted for } 8.1 \% \text { of the total facilities. }\end{array}$} \\
\hline
\end{tabular}

Table 3 provides the results from the regression to assess the determinants of the efficiency scores when pooling all heath facilities. Compared to $\mathrm{CHCs}$, the efficiency score of BHCs and SHCs were lower by 0.108 and 0.071 respectively. Hardship was negatively associated with technical efficiency. We also found that higher share of supporting staff was associated with lower technical efficiency while higher share of capital costs was associated with higher efficiency. One percentage point increase in supporting staff was associated with a reduction of 0.17 percentage points in efficiency $(p<0.05) .1$ percentage point increase in capital costs was associated with an increase of 0.28 percentage points in efficiency ( $p$ $<0.001)$.

Table 3

Determinants of the pooled technical efficiency 


\begin{tabular}{|c|c|c|c|c|c|}
\hline \multirow{2}{*}{$\begin{array}{l}\text { Pooled efficiency score } \\
\text { BHCs }\end{array}$} & \multirow{2}{*}{$\begin{array}{l}\text { Coefficient } \\
\text { (Standard error) } \\
-0.108^{\star \star \star} \\
(0.018)\end{array}$} & \multirow{2}{*}{$\begin{array}{l}\mathbf{t} \\
-6.07\end{array}$} & \multirow{2}{*}{$\begin{array}{l}P>t \\
0.000\end{array}$} & \multicolumn{2}{|c|}{$95 \%$ confidence interval } \\
\hline & & & & -0.143 & -0.073 \\
\hline SHCs & $\begin{array}{l}-0.071 \star \star \star \\
(0.019)\end{array}$ & -3.79 & 0.000 & -0.108 & -0.034 \\
\hline Hardship province 2 & $\begin{array}{l}-0.096 * \star * \\
(0.021)\end{array}$ & -4.58 & 0.000 & -0.138 & -0.055 \\
\hline Hardship province 3 & $\begin{array}{l}-0.141 \text { *** } \\
(0.021)\end{array}$ & -6.65 & 0.000 & -0.182 & -0.099 \\
\hline Hardship province 4 & $\begin{array}{l}-0.185^{\star \star \star *} \\
(0.021)\end{array}$ & -8.72 & 0.000 & -0.226 & -0.143 \\
\hline$\%$ supporting staff & $\begin{array}{l}-0.170 \star * \\
(0.086)\end{array}$ & -1.97 & 0.049 & -0.339 & -0.001 \\
\hline$\%$ capita costs & $\begin{array}{l}0.357 * \star \star \\
(0.051)\end{array}$ & 7.04 & 0.000 & 0.258 & 0.457 \\
\hline Constant & $\begin{array}{l}0.947 * \star * \\
(0.033)\end{array}$ & 29.1 & 0.000 & 0.883 & 1.011 \\
\hline
\end{tabular}

\section{Discussion}

This study analyzed the relative efficiency of three levels of public primary healthcare facilities in Afghanistan operated by NGOs. We found that different types of health facilities delivered BPHS with varying degrees of efficiency. Providing primary healthcare in CHCs was more efficient than in BHCs and SHCs. Our results also demonstrate potential areas where improvements in resource allocation and use could lead to more efficient health service provision.

Average separate efficiency scores in our study ranged $0.73-0.90$ for the different levels. This finding is consistent with efficiency scores calculated using a similar methodology in other countries [,]. We found that facilities that provide more comprehensive care are more efficient, and therefore have limited room for potential efficiency gains. In contrast, lower-level facilities are less efficient, and therefore may have more room for improvement in efficiency.

Studies conducted in some developing countries report that the majority of primary healthcare facilities are relatively inefficient. For example, a study in Ghana found that $78 \%$ of primary health facilities were inefficient [ and a study in South Africa determined that $70 \%$ of primary healthcare facilities were 
inefficient [. Our findings show that $60 \%$ of BHCs and SHCs have average efficiency scores of 0.70 or less which make them relatively inefficient.

In addition, we found that the difference in efficiency between the lowest and highest efficiency quintiles, was much broader in facilities that offer fewer services (a range between mean separate efficiency of the highest and lowest quintiles of 0.15 in $\mathrm{CHCs}, 0.26$ in BHCs, and 0.39 in SHCs). The last two offer fewer services than $\mathrm{CHCs}$.

At the lower level health facilities (BHCs and SHCs), we found a wide range of efficiency scores. The separate efficiency score for the lowest quintile of BHCs and SHCs were 0.67 and 0.58 respectively, suggesting that $32.9 \%$ and $42.5 \%$ of resources could be saved in each facility type, while maintaining the same level of care. Our multivariate analysis confirmed these findings. In order to put this into perspective, in total, USD\$7.14 million could be saved had all BHCs and SHCs performed to the level of their most efficient peers. Alternatively, the less efficient health facilities could also increase their outputs with the same level of inputs.

Capital investment in health facilities has been associated with better performance of health facilities in terms of efficiency. This is understandable, especially when the investment is in very needed technologies that once purchased will run for many years. On the other hand, better equipped health facilities will be able to serve more consumers due to efficient use of staff time and higher people trust in the health facility. However, while supporting staff contribution to the cleanliness and safety of health facilities is essential, their share as percentage of total health facility expenditure has been associated with lower efficiency. This should be studied further.

A study in Ghana found that health facilities in urban areas were performing relatively more efficiently compared to rural health facilities [5]. While we did not consider urban vs. rural locations, our findings confirm the importance of geography. Multivariate analysis showed that provinces with a higher hardship scores, reflecting among other parameters, remoteness and more serious security considerations, are working less efficiently.

Several limitations of this study should be acknowledged. First, the EMIS collects capital expenditure, but it does not consider depreciation. However, since depreciation is likely to be even among the types of facilities, we do not expect this to affect our findings. Second, the expenditure incurred in the study period (2016 calendar year) may not necessarily have been used to fund service delivery in the same time period, as some health facilities may have procured medicine for 2017 at the end of 2016 . However, some facilities may have procured commodities in 2015 that were used in 2016 and were not measured in our data. We expect that these cancel each other, reducing the possibility of bias.

\section{Conclusion}

This study shows that higher level health facilities are relatively more efficient in providing BHIS in Afghanistan, and that smaller facilities have more room for improvement. Share of supporting staff and 
the capital investment in health facilities are associated with the efficiency of delivery the services to targeted population. Policy makers and NGO program managers can use our findings to examine where to improve efficiency in use of resources in primary health facilities.

\section{Declarations}

Ethics approval and consent to participants

Not applicable

Consent for publication

Not applicable

Availability of data and materials

The datasets used and analyzed during the current study are available from the corresponding author on reasonable request.

\section{References}

1. . Afghanistan Ministry of Public Health (MoPH). Afghanistan National Health Accounts, Report. 2017. Kabul, Afghanistan: MoPH.

2. . Afghanistan Ministry of Public Health (MoPH). Potential avenues to increase government investment in health in Afghanistan, Report. 2016.

3. . Afghanistan Ministry of Public Health (MoPH). MOPH health financing strategy 2016-2020. 21. Kabul, Afghanistan: MoPH.

4. . Evans, DB, and Etienne, C. Health systems financing and the path to universal coverage. B World Health Organ. 2010; 88:402-402. doi: 10.2471/BLT.10.078741. Accessed 10 September 2019.

5. . Novignon, J, and Nonvignon, J. Improving primary healthcare facility performance in Ghana: Efficiency analysis and fiscal space implications. BMC Health Serv Res. 2017; 17(1):1-8. https://bmchealthservres.biomedcentral.com/articles/10.1186/s12913-017-2347-4. Accessed 10 September 2019.

6. . Das, JK, Akseer, N, Mirzazada, S, Peera, Z, Noorzada, O, Armstrong, CE, Mukhtar, K, Naeem, AJ, and Bhutta, ZA. Scaling up primary health services for improving reproductive, maternal, and child health: a multisectoral collaboration in the conflict setting of Afghanistan. bmj. 2018 Dec 7;363:k4986. doi: 10.1136/bmj.k4986. Accessed 10 September 2019.

7. . Blaakman, A, and Lwin A. Afghanistan Basic Package of Health Services: Cost-Efficiency, Quality, Equity and Stakeholder Insights into Contracting Modalities. 2013. Washington, DC: Health Policy Project. https://www.healthpolicyproject.com/index.cfm?id=publications\&get=pubID\&publd=245. Accessed 10 September 2019. 
8. . Coelli, TJ, O'Donnel, CJ, and Battese, GE. An Introduction to Efficiency and Productivity Analysis (2nd edition). Australia: Springer, 2005.

9. . Zeng, W, Shepard, DS, Chilingerian, and J, Avila-Figueroa, C. How much can we gain from improved efficiency? An examination of performance of national HIV/AIDS programs and its determinants in low- and middle-income countries. BMC Health Serv Res. 2012;12:74. https://bmchealthservres.biomedcentral.com/articles/10.1186/1472-6963-12-74. Accessed 10 September 2019.

10. . Sherman, HD. Hospital Efficiency Measurement and Evaluation. Medical Care, 1984; 22,10:922-938. Doi: 10.1097/00005650-198410000-00005. Accessed 10 September 2019.

11. . Marschall, P, and Flessa, S. Efficiency of primary care in rural Burkina Faso. A two-stage DEA analysis. Health economics review. 2011; 1(1):5. doi: 10.1186/2191-1991-1-5. Accessed 10 September 2019.

12. . Renner, A, Kirigia, JM, Zere, EA, Barry, SP, Kirigia, DG, Kamara, C, and Muthuri, LH. Technical efficiency of peripheral health units in Pujehun district of Sierra Leone: a DEA application. BMC health services research. 2005;5(1):77. doi: 10.1186/1472-6963-5-77. Accessed 10 September 2019.

13. . Novignon, J, and Nonvignon, J. Improving primary health care facility performance in Ghana: efficiency analysis and fiscal space implications. BMC health services research. 2017; 17(1):399. Doi: 10.1186/s12913-017-2347-4. Accessed 10 September 2019.

14. . Akazili, J, Adjuik, M, Chatio, S, Kanyomse, E, Hodgson, A, Aikins, M, and Gyapong J. What are the technical and allocative efficiencies of public health centres in Ghana?. Ghana medical journal. 2008;42 (4):149-55. doi: https://www.ncbi.nlm.nih.gov/pubmed/19452023. Accessed 10 September 2019.

15. . Kirigia, JM, Sambo, L, Scheel, H: Technical efficiency of public clinics in Kwazulu-Natal province of South Africa. East Afr Med J. 2001; 78:1-3.

\section{Figures}


Figure 1: Efficiency scores quintile by health facility level

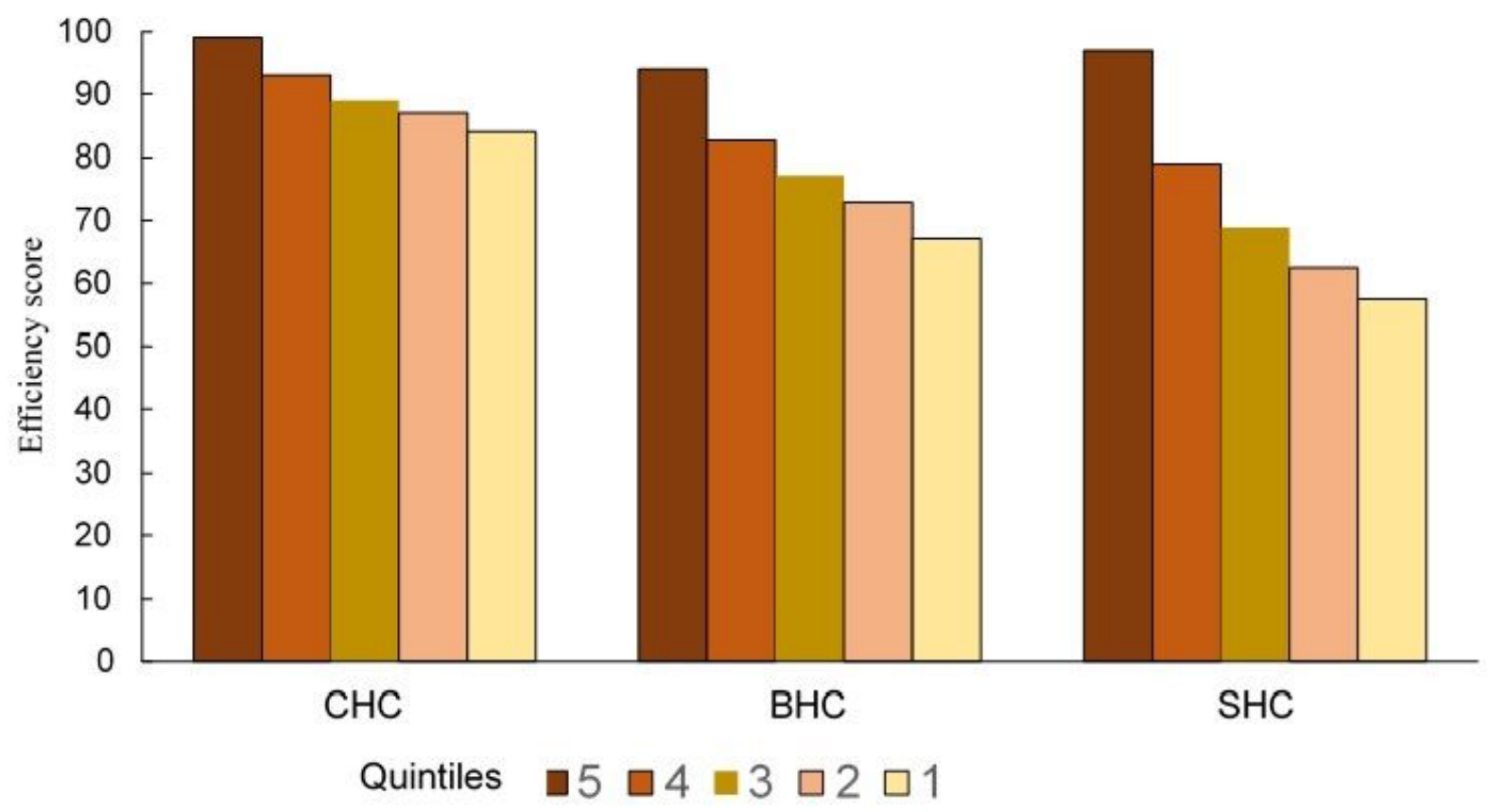

Figure 1

shows efficiency scores for the three facility types. Since the efficiency score variable is continuous, we created score quintiles, with facilities with the lowest scores in the first quintile, and those with the highest score in the fifth. On average, $\mathrm{CHCs}, \mathrm{BHCs}$ and SHCs have efficiency scores of $0.90,0.79$, and 0.73 respectively. 
Figure 2: Efficiency scores from pooled DEA

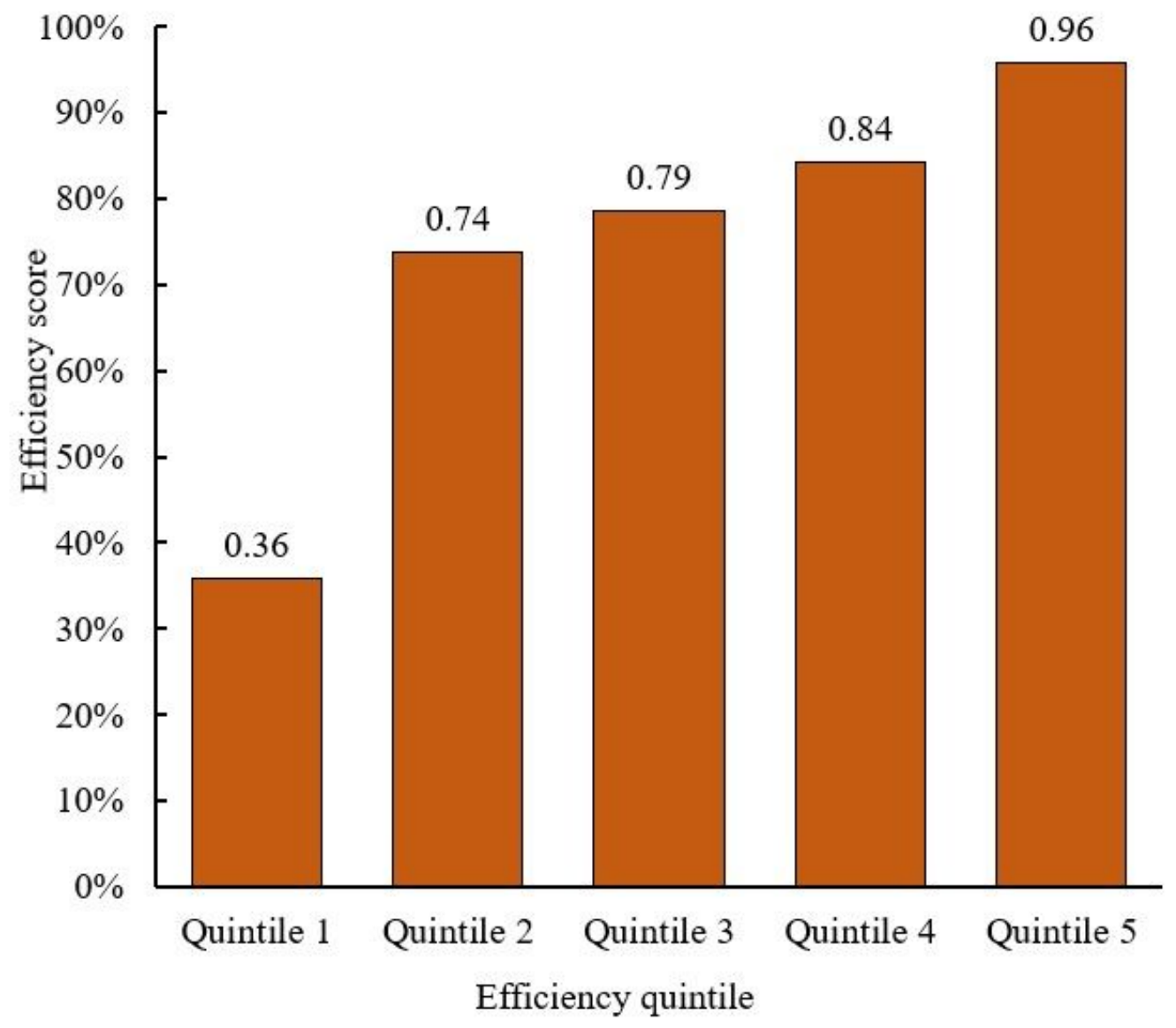

\section{Figure 2}

shows the pooled efficiency scores by quintile. The facilities with the lowest efficiency scores had an average of score of 0.36 . The average efficiency scores for the remaining quintiles were $0.74,0.79,0.84$ and 0.96. The average efficiency scores for CHCs, BHCs, and SHCs were $0.81,0.71$ and 0.73 , respectively, and the differences were statistically significant $(F=16.12, p<0.001)$. 